\title{
Grazing of heterotrophic nanoflagellates on the eukaryotic picoautotroph Choricystis sp.
}

\author{
Grażyna Bręk-Laitinen*, Anne Ojala
}

Department of Environmental Sciences, University of Helsinki, Niemenkatu 73, 15140 Lahti, Finland

\begin{abstract}
Autotrophic picoplankton (APP, $<2 \mu \mathrm{m})$, composed of both prokaryotes and eukaryotes, play an important role in the production and transformation of organic carbon in freshwaters. Eukaryotic APP are commonly found in winter and spring, and heterotrophic nanoflagellates (HNF) are regarded as significant consumers of APP. Here, we analysed the grazing impact and the growth ability of the HNF culture derived from a boreal clearwater lake on the picoalga Choricystis sp. For comparison, we used HNF monocultures of Rhynchomonas sp. and Bodo saltans flagellates with distinct feeding behaviours. In the grazing experiments, all HNF cultures ingested picoalgae and reached feeding rates between 0.08 and 0.81 cells $\mathrm{HNF}^{-1} \mathrm{~h}^{-1}$. We observed large species-specific differences in grazing rate $\left(0.97\right.$ to $\left.1.96 \mathrm{~d}^{-1}\right)$, growth rate $\left(0.35\right.$ to $\left.0.85 \mathrm{~d}^{-1}\right)$ and final abundance of HNF $\left(5.6 \times 10^{4}\right.$ to $\left.74.2 \times 10^{4}{\left.\text { cells } \mathrm{ml}^{-1}\right)}\right)$ in the growth experiments. Surprisingly, we found an increase in picoalgal growth in the presence of a grazing HNF population. Although HNF appear to be active herbivores capable of significantly reducing APP stock, flagellates were unable to control the picoalgal population. Overall, this study demonstrates an unexpected role of HNF in microbial food webs by imposing a positive feedback on picoalgal growth through grazing.
\end{abstract}

KEY WORDS: Heterotrophic nanoflagellates · Picoeukaryotes · Grazing - Choricystis sp. · Rhynchomonas sp. B Bodo saltans

\section{INTRODUCTION}

Autotrophic picoplankton (APP) contribute up to $90 \%$ of total carbon production and phytoplankton biomass in global oceans (Stockner 1988). APP can also occur at high cell densities in freshwater ecosystems and account for the bulk of primary production during the growing season (Callieri \& Stockner 2002). Data from other times of the year are scarce, and it is commonly believed that APP are of little importance in winter (Vörös et al. 1991). Recent observations have shown that in some lakes, APP are most abundant in winter, under the ice-cover (Mózes \& Vörös 2004, Straškrábová et al. 2005). From winter to early spring, APP communities are mainly composed of eukaryotic picoalgae and some phycocyanin-rich picocyanobacteria (Mózes et al. 2006, Ivanikova et al. 2007). The genus Choricystis is widely found among freshwater picoalgae (Zidarova et al. 2009 and references therein).
The major loss processes among APP are grazing, viral lysis and sedimentation, each of which has a specific impact on carbon dynamics (Richardson \& Jackson 2007). However, due to the small size of APP (cell diameter $<2 \mu \mathrm{m})$, losses through sinking without aggregations are regarded as negligible. Viral lysis has a low to intermediate impact on APP populations (Baudoux et al. 2008, Personnic et al. 2009). Therefore, it is important to quantify the grazing losses, especially those due to microzooplankton, since mesozooplankton grazing is mainly possible for aggregated forms of APP (Richardson \& Jackson 2007). Among microzooplankton, heterotrophic nanoflagellates (HNF) and small ciliates are the major consumers of APP (Weisse 1993, Guillou et al. 2001). HNF are a functionally diverse group with different feeding strategies, including bacterivory, algivory or osmotrophy (Sherr \& Sherr 2002). Little attention has been paid to the potential role of APP as a food source for HNF, even though some HNF are known to prefer APP over bacterio- 
plankton (Christaki et al. 2001), thereby forming the major pathway of picoalgal carbon transport to higher trophic levels (Stockner 1988). Knowledge about grazing on eukaryotic APP is limited, and the majority of studies have concentrated on prokaryotic Synechococcus and Prochlorococcus (Worden et al. 2004). To the best of our knowledge, only 2 studies to date (Parslow et al. 1986, Christaki et al. 2005) have reported species-specific grazing of nanoflagellates on eukaryotic picoalgae, both in marine environments, while no parallel data on the grazing of freshwater HNF on Choricystis exist.

Grazing studies have mainly been based on such approaches as size fractionation, dilution, use of specific inhibitors or disappearance of prey analogues (Caron et al. 1991, Landry et al. 1995, Liu et al. 1995, Šimek et al. 1997, Worden \& Binder 2003). However, these methods rely on communities and do not consider the different feeding modes of HNF. Investigation of prey items in the food vacuole of a single flagellate at a high resolution enables calculations of ingestion and clearance rates (Landry et al. 1995). Additionally, chlorophyll-containing autofluorescing cells of APP can easily be seen in food vacuoles of HNF without using fluorescing dyes (Dolan \& Šimek 1998).

Here we quantified the grazing impact of HNF on eukaryotic APP and also examined the potential of HNF to control APP at low temperatures. Our simple 2step experimental set-up consisted of 1 defined prey item, i.e. a rod-shaped unicellular Choricystis sp., and 3 different types of HNF as grazers, i.e. Bodo saltans Ehrenberg, Rhynchomonas sp. and a mixed HNF culture derived from a lake winter assemblage. The HNF taxa chosen for this study are in the size class that is most abundant in temperate lakes in spring (Auer \& Arndt 2001) and show the highest taxon-specific uptake rates of small prey items (Šimek et al. 1997). These HNF are known to feed on APP and large bacteria (Sherr et al. 1992), and thus can shape picoplankton communities (Šimek et al. 1999). B. saltans is described as an interceptive and Rhynchomonas sp. as a raptorial feeder. The classical protistology terms 'interceptive' and 'raptorial' feeders are often used synonymously (Fenchel 1987). In this study, we recognise the variety of feeding mechanisms, and the term 'interceptive' is used for HNF producing currents and directly intercepting food particles, while the term 'raptorial' describes mobile protozoa actively searching for food particles (Boenigk \& Arndt 2000a).

The mixed HNF culture came from Lake Vesijärvi, a large meso-eutrophic clearwater lake in southern Finland (Keto et al. 2005). During the growing season, APP are abundant and mainly comprise picocyanobacteria, which contribute up to $55 \%$ of total phytoplankton primary production (G. Bręk-Laitinen et al. unpubl.). When the lake is ice-covered, large redfluorescing cells dominate in APP (G. Bręk-Laitinen et al. unpubl.). Despite the obvious importance of APP in this lake, no studies exist on transfer of APP carbon to higher trophic levels.

In short-term experiments, we examined the effects of APP density on HNF feeding rates and analysed grazing parameters, i.e. ingestion rates, clearance rates and grazing impact, under conditions in which the influence of changes in grazer concentration was minimised. Ingestion of picoalgae was defined by direct microscopical counts of prey items inside the food vacuoles of HNF on the basis of chlorophyll a (chl a) autofluorescence. In longer experiments, we determined the growth of HNF when Choricystis sp. was supplied as a food source.

This study is part of a project examining the microbial food web and APP in boreal lakes where we also studied in more detail the seasonal dynamics and community composition of APP using molecular techniques, the role of biomanipulation in the microbial food web and the carbon gas fluxes.

\section{MATERIALS AND METHODS}

Cultures. The freshwater picoplanktonic alga Choricystis sp. (Trebouxiophyceae), originally isolated from an ice-covered pond, was provided by the ProvasoliGuillard National Center for Culture of Marine Phytoplankton (CCMP) in Bigelow, Maine, USA (strain no. CCMP2201). We grew the non-axenic strain in $500 \mathrm{ml}$ conical flasks in modified DY-V medium (for details, see https://ccmp.bigelow.org/node/119). Initially, we attempted to maintain the stock culture at $10^{\circ} \mathrm{C}$, but without success, and thus, it was kept at $20^{\circ} \mathrm{C}$. However, the stock culture did show acclimation to $10^{\circ} \mathrm{C}$, when gradually transferred from 20 to $10^{\circ} \mathrm{C}$ with a temperature decrease of $3^{\circ} \mathrm{C}$ per week over the $4 \mathrm{wk}$ period, but not if transferred abruptly from 20 to $10^{\circ} \mathrm{C}$. Thus, in the experiments we used temperatureacclimatised cultures. Light was provided from coolwhite fluorescent tubes with a photon flux density of $200 \mu \mathrm{mol} \mathrm{m}{ }^{-2} \mathrm{~s}^{-1}$ and a light:dark cycle of 12:12 h. At $10^{\circ} \mathrm{C}$, the Choricystis sp. stock culture attained a specific growth rate of $0.89 \mathrm{~d}^{-1}$, a maximum cell density of $6.5 \times 10^{6} \mathrm{ml}^{-1}$ and a size of 1.0 to $2.7 \times 0.5$ to $1.4 \mu \mathrm{m}$ with a mean elongation factor of 1.5 .

The non-axenic cultures of Bodo saltans (strain no. CCAP 1907/6) and Rhynchomonas sp. (strain no. CCAP 1972/2), both of which have 2 flagella, were obtained from the Culture Collection of Algae and Protozoa (CCAP) in Oban, Argyll, UK. The bean-shaped B. saltans measures 4 to $5 \mu \mathrm{m}$, whereas Rhynchomonas $\mathrm{sp}$. is 5 to $10 \mu \mathrm{m}$ long with a bulbous rostral region. 
Three weeks prior to the experiments, the flagellate cultures were established in $2000 \mathrm{ml}$ conical flasks. For B. saltans, the growth medium consisted of soil extract enriched with salts (for details, see www.ccap.ac.uk/ media/pdfrecipes.htm), while Rhynchomonas sp. was grown in Chalkley's medium (Haberey \& Stockem 1971). Both media were completed with a mixture of $90 \%$ bacto-peptone and $10 \%$ yeast extract to a final concentration of $20 \mathrm{mg} \mathrm{l}^{-1}$ and finally, some wheat grains were added to the flasks. Cultures were maintained in the dark at $10^{\circ} \mathrm{C}$ to assure acclimatisation to the low temperature and fully heterotrophic growth.

The natural assemblage of HNF was collected in February, 3 wk before the onset of the experiments from the deepest point of the southernmost basin of Lake Vesijärvi. The below-ice water was collected to a $10 \mathrm{~m}$ depth with an acrylic tube sampler (Limnos, volume $7.0 \mathrm{l}$, length $1.0 \mathrm{~m}$ ). The $3 \mathrm{l}$ subsample was immediately passed through a $100 \mu \mathrm{m}$ nylon net to remove large zooplankton. Prefiltered water was transported in a darkened container on ice to the laboratory, where it was further filtered gently by means of gravity through $8 \mu \mathrm{m}$ polycarbonate filters (Osmonics). Flagellates were then collected onto $0.8 \mu \mathrm{m}$ polycarbonate filters (Osmonics) using low pressure filtration, gently washed out from the filters and suspended briefly in $100 \mathrm{ml}$ of de-ionised water. The stock culture of the mixed HNF was established in a $2000 \mathrm{ml}$ conical flask in which the HNF concentrate was added, filled up to $1000 \mathrm{ml}$ with Chalkley's medium and completed with a bacto-peptone and yeast extract mixture. The mixed HNF culture was maintained heterotrophically in the dark at $10^{\circ} \mathrm{C}$.

Experiments. The short-term experiment, where the intention was to examine the effects of APP density on HNF ingestion, was started by transferring $250 \mathrm{ml}$ aliquots of exponentially growing HNF cultures to $500 \mathrm{ml}$ conical flasks at $10^{\circ} \mathrm{C}$. The experiment was carried out in the light and started $1 \mathrm{~h}$ after the fluorescent tubes $\left(200 \mu \mathrm{mol} \mathrm{m}{ }^{-2} \mathrm{~s}^{-1}\right)$ were switched on. We used an incubation time of $9 \mathrm{~h}$ since we anticipated cell ingestion to be slow at this temperature (Sherr et al. 1988). We applied 3 different densities of APP to each type of HNF culture (see Table 1). Samples for counting APP and HNF were taken at 15 min intervals during the first hour of the experiment and thereafter every $3 \mathrm{~h}$ until the end of the experiment.

The duplicated growth experiment, where Choricystis served as a food of HNF, lasted for $6 \mathrm{~d}$. To start the experiment, $500 \mathrm{ml}$ conical flasks with $250 \mathrm{ml}$ of late exponential phase APP culture (density between $2.9 \times 10^{6}$ and $6.0 \times 10^{6}$ cells $\mathrm{ml}^{-1}$ ) were spiked with exponentially growing cultures of Bodo saltans, Rhynchomonas sp. and the mixed culture of HNF such that the final flagellate density was between $3.1 \times 10^{4}$ and
$4.6 \times 10^{4}$ cells ml ${ }^{-1}$. Additional flasks with Choricystis sp. for each HNF treatment served as controls for APP and bacterial growth. The control culture was prepared by adding to the APP culture HNF culture medium where flagellates were removed by filtering the medium through a $0.2 \mu \mathrm{m}$ filter. Thus, controls received a medium in which HNF had grown, but was now HNF-free. The growth experiment-including the controls - was conducted with the same irradiance levels and light and dark cycles as used for the stock culture of APP. The experiment started $1 \mathrm{~h}$ after the lights in the growth cabinet were switched on. Samples for APP, bacteria and HNF counts were taken at the onset of the experiments and thereafter twice a day, i.e. $1 \mathrm{~h}$ after lights on and $2 \mathrm{~h}$ before lights off.

Enumeration of samples. HNF and bacteria samples were fixed immediately after sampling with a combination of alkaline Lugol's solution (final concentration $\sim 3 \%$ ) and buffered formalin (final concentration $\sim 1 \%$ ), while APP samples were fixed only with formalin (final concentration $\sim 2 \%$ ). All samples were stored in tightly closed plastic vials in the dark at $4^{\circ} \mathrm{C}$ before being counted within $3 \mathrm{wk}$ (Sato et al. 2006). Just before counting, HNF and bacteria samples were decolourised with a saturated solution of sodium thiosulphate and stained for $10 \mathrm{~min}$ in the dark with 4',6diamidino-2-phenylindole (DAPI; final concentration $1 \mu \mathrm{g} \mathrm{ml}^{-1}$ ). Stained HNF and bacteria samples were filtered with a vacuum pump $(\mathrm{p}<20 \mathrm{mmHg}$ ) onto $0.8 \mu \mathrm{m}$ and $0.2 \mu \mathrm{m}$ black polycarbonate membrane filters (Osmonics), respectively. Cells were enumerated with a Nikon Eclipse E600 microscope equipped with an epifluorescence attachment using a UV filter (excitation $365 \mathrm{~nm}$, emission $420 \mathrm{~nm}$ ) and a total magnification of $1000 \times$ for bacteria and $400 \times$ for HNF. APP samples were filtered onto $0.2 \mu \mathrm{m}$ black polycarbonate filters (Osmonics) and counted with the epifluorescence microscope using 400× magnification and excitation at 510 to $560 \mathrm{~nm}$ and emission at $590 \mathrm{~nm}$. For each group of organisms, at least 50 random fields of view per sample were counted (Guillard \& Sieracki 2005). Food vacuoles of $50 \mathrm{HNF}$ cells were inspected under blue light (excitation 450 to $490 \mathrm{~nm}$, emission $515 \mathrm{~nm}$ ) and green light (excitation 510 to $560 \mathrm{~nm}$, emission $590 \mathrm{~nm}$ ) to enumerate the ingested APP cells which had bright yellow-green and dim red autofluorescence, respectively. The size of 100 APP and HNF cells per sample was measured from digital images (Nikon DS-5Mc) using NIS-Elements v. 2.2 (Nikon Instruments) image analysing software. The mean cell densities as well as the length and width of cells were used to estimate biovolumes of APP and HNF by assuming an ellipsoidal cell shape. The biovolumes were then converted to carbon biomass using a factor of $250 \mathrm{fg} \mathrm{C} \mathrm{mm}^{-3}$ for APP (Søndergaard 1991) and 


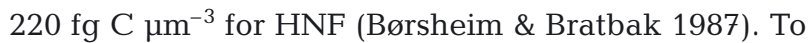
estimate bacterial biomass we used a factor of $35 \mathrm{fg} \mathrm{C}$ cell $^{-1}$ (Theil-Nielsen \& Søndergaard 1998).

Rate calculations. Calculations of ingestion rates (Choricystis $\mathrm{HNF}^{-1} \mathrm{~h}^{-1}$ ) were based on counts of food vacuole content (Boenigk et al. 2001) during the shortterm experiment. Feeding rates (Choricystis $\mathrm{HNF}^{-1} \mathrm{~h}^{-1}$ ) were calculated from the slope of the linear regression of the average number of prey items per HNF cell versus time (Dolan \& Šimek 1998) using 5 time points. The rates of HNF feeding on Choricystis were calculated without correcting for the growth of either Choricystis or HNF (Dolan \& Šimek 1998). Clearance rates (nl $\mathrm{HNF}^{-1} \mathrm{~h}^{-1}$ ) were obtained by dividing feeding rates by the mean density of APP over the grazing period (Heinbokel 1978).

The volume-specific clearances $\left(\mathrm{h}^{-1}\right)$ were calculated by dividing the clearance rates by the mean volume of the flagellates. The community grazing impacts (Choricystis $\mathrm{ml}^{-1} \mathrm{~h}^{-1}$ ) were related to quantities of APP removed by the HNF community and were computed by multiplying feeding rates by HNF densities and transformed to carbon equivalents using a volumebased biomass factor (Søndergaard 1991). Carbon uptake of HNF was expressed as a percentage reduction of standing stock of APP $\mathrm{h}^{-1}$.

The calculations of average growth rates were based on the cell counts in the long-term grazing experiment. Specific growth rates $\left(\mu, \mathrm{d}^{-1}\right)$ during the exponential growth phase of each HNF culture were calculated as the slope of the regression line using the log-transformed data. Doubling time $D\left(\mathrm{~d}^{-1}\right)$ of HNF was estimated as (Loret et al. 2000):

$$
D=(\ln 2) / \mu
$$

Grazing rates of HNF on APP were determined as the slope of the linear regression between the APP concentration at the beginning of the experiment and at the time of the lowest APP concentration. The rationale of these calculations is based on the control flasks, where there were no changes in APP population density during that time, i.e. all changes in the treatment bottles were assumed to be due to grazing. Intrinsic growth rates of APP were calculated as the sum of grazing rate and exponential growth rate in treatments.

Result were analysed statistically using 1-way analysis of variance (ANOVA) followed by a post hoc pairwise comparison test (Bonferroni) at a significance level of $\mathrm{p}<0.05$ (SPSS 15.0 for Windows). Replicates were compared using a simple 2-tailed $t$-test. For each HNF, the influence of APP concentration on ingestion rate was tested using analysis of covariance (ANCOVA).

\section{RESULTS}

\section{Ingestion experiment}

Bodo saltans, Rhynchomonas sp. and the mixed HNF culture actively ingested APP at all concentrations (Fig. 1). Since the HNF cultures were non-axenic, flagellates fed on APP in the presence of heterotrophic bacteria. The mean $( \pm \mathrm{SD})$ concentration of bacteria at the onset of the experiment was $1.39( \pm 0.23) \times 10^{7}$ cells $\mathrm{ml}^{-1}, 0.5( \pm 0.12) \times 10^{7}$ cells ml ${ }^{-1}$ and $0.5( \pm 0.22) \times 10^{7}$ cells $\mathrm{ml}^{-1}$ for $B$. saltans, Rhynchomonas sp. and the mixed HNF culture, respectively. The starting densities of Choricystis ranged from $0.06 \times 10^{5}$ to $11.6 \times 10^{5}$ cells $\mathrm{ml}^{-1}$, while the corresponding APP to bacteria carbon ratio varied from 0.01 to 2.24 (Table 1 ). The grazing parameters were calculated for the first hour of the experiment, when the prey uptake was close to linear in all treatments, i.e. contrary to our expectations, uptake was fast even at this low temperature (Fig. 1). In all HNF cultures, prey uptake significantly differed between treatments with varying APP concentrations

Table 1. Initial experimental conditions and grazing parameters in the ingestion experiment, where heterotrophic nanoflagellates (HNF) fed on Choricystis sp. at 3 different concentrations (L: low, M: medium, H: high)

\begin{tabular}{|c|c|c|c|c|c|c|c|c|c|}
\hline & \multicolumn{3}{|c|}{ Bodo saltans } & \multicolumn{3}{|c|}{ Rhynchomonas sp. } & \multicolumn{3}{|c|}{ Mixed culture } \\
\hline & $\mathrm{L}$ & M & $\mathrm{H}$ & $\mathrm{L}$ & M & $\mathrm{H}$ & $\mathrm{L}$ & M & $\mathrm{H}$ \\
\hline Picoalgae concentration $\left(\times 10^{5}\right.$ cells ml $\left.\mathrm{ml}^{-1}\right)$ & 0.06 & 0.44 & 2.61 & 0.23 & 0.53 & 11.6 & 0.12 & 1.17 & 5.15 \\
\hline Bacteria concentration $\left(\times 10^{7}\right.$ cells ml $\left.{ }^{-1}\right)$ & 1.33 & 1.64 & 1.19 & 0.64 & 0.54 & 0.39 & 0.25 & 0.69 & 0.48 \\
\hline HNF concentration $\left(\times 10^{4}\right.$ cells ml $\left.^{-1}\right)$ & 2.27 & 1.37 & 1.60 & 0.52 & 0.61 & 0.61 & 1.62 & 2.76 & 2.10 \\
\hline Picoalgae to bacteria carbon ratio & $<0.01$ & 0.02 & 0.16 & 0.03 & 0.07 & 2.24 & 0.04 & 0.13 & 0.81 \\
\hline Picoalgae to HNF cell ratio & 0.02 & 0.32 & 1.64 & 0.45 & 0.87 & 18.9 & 0.07 & 0.43 & 2.45 \\
\hline Ingestion rate (cells $\mathrm{HNF}^{-1} \mathrm{~h}^{-1}$ ) & 0.12 & 0.24 & 0.81 & 0.17 & 0.38 & 0.08 & 0.16 & 0.25 & 1.05 \\
\hline Clearance rate $\left(\mathrm{nl} \mathrm{HNF}{ }^{-1} \mathrm{~h}^{-1}\right)$ & 202 & 54.1 & 30.9 & 71.8 & 72.2 & 0.71 & 133 & 21.0 & 20.4 \\
\hline Specific clearance rate $\left(\times 10^{5}\right.$ body volume $\left.\mathrm{h}^{-1}\right)$ & 31.1 & 8.36 & 4.77 & 12.0 & 12.0 & 0.12 & 15.2 & 2.41 & 2.34 \\
\hline Community grazing impact $\left(\times 10^{3}\right.$ cells $\left.\mathrm{ml}^{-1} \mathrm{~h}^{-1}\right)$ & 2.89 & 3.24 & 12.9 & 0.87 & 2.35 & 0.51 & 2.55 & 6.81 & 22.1 \\
\hline Community grazing impact $\left(\mu \mathrm{g} \mathrm{C} \mathrm{l}^{-1} \mathrm{~h}^{-1}\right.$ ) & 0.52 & 0.58 & 2.33 & 0.16 & 0.42 & 0.09 & 0.46 & 1.23 & 3.98 \\
\hline Picoalgal carbon uptake ( $\%$ of standing stock $\mathrm{h}^{-1}$ ) & 4.98 & 0.74 & 0.49 & 0.37 & 0.44 & $<0.01$ & 2.16 & 0.58 & 0.43 \\
\hline
\end{tabular}



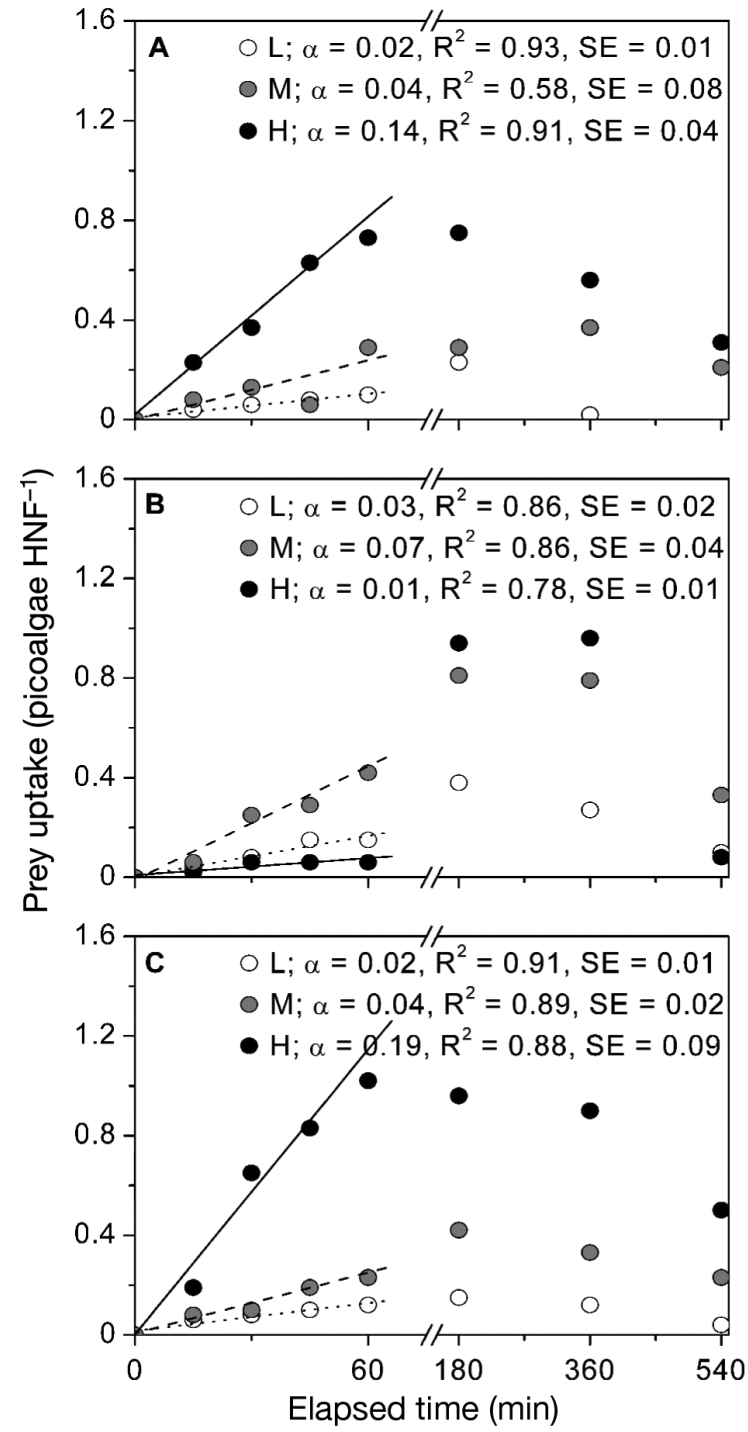

Fig. 1. Prey uptake by (A) Bodo saltans, (B) Rhynchomonas sp. and $(\mathrm{C})$ the mixed culture of heterotrophic nanoflagellates (HNF) on different availabilities of Choricystis sp. as prey. L (low), $\mathrm{M}$ (medium) and $\mathrm{H}$ (high) refer to treatments with different autotrophic picoplankton (APP) concentrations at the beginning of the experiment (values are given in Table 1). Linear regression models were fit to the first hour of data. SE: standard errors of slopes

(ANCOVA, $\mathrm{n}=15 ; F=5.87, \mathrm{p}=0.02 ; F=7.96, \mathrm{p}=$ 0.007 ; and $F=9.84, \mathrm{p}=0.003$ for B. saltans, Rhynchomonas sp. and mixed HNF culture, respectively). HNF concentrations did not change over the $9 \mathrm{~h}$ experimental period (results not shown).

We evaluated the coefficients of the regression lines between APP concentrations and ingestion rates, and these tests showed that the grazing parameters differed significantly for each type of grazer (ANOVA, $F=$ $37.7, \mathrm{p}=0.007$ ). The ingestion rates depended on food concentration and usually increased with increasing
APP to HNF ratios (Table 1). However, for Rhynchomonas sp. the ingestion was lowest, 0.08 APP cells $\mathrm{HNF}^{-1} \mathrm{~h}^{-1}$, in cultures with the highest APP concentra-

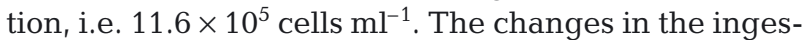
tion rates of Bodo saltans and the mixed HNF culture were similar, increasing with increasing APP densities, i.e. from 0.12 to 0.81 cells $\mathrm{HNF}^{-1} \mathrm{~h}^{-1}$ and from 0.16 to 1.05 cells $\mathrm{HNF}^{-1} \mathrm{~h}^{-1}$ for $B$. saltans and the mixed HNF culture, respectively (Table 1 ).

Clearance rates varied by 3 orders of magnitude, i.e. from 0.71 to $202 \mathrm{nl} \mathrm{HNF}{ }^{-1} \mathrm{~h}^{-1}$, and were inversely related to APP concentration, with the highest rates at the lowest prey densities (Table 1). Bodo saltans and Rhynchomonas sp. cleared Choricystis at different rates, i.e. 54.1 and $72.2 \mathrm{nl} \mathrm{HNF}^{-1} \mathrm{~h}^{-1}$, respectively, at similar APP concentration (0.43 to 0.53 APP cells $\mathrm{ml}^{-1}$ ). Thus, Rhynchomonas sp. was $25 \%$ more effective in searching for prey than B. saltans. There was also a difference between these 2 flagellates in specific clearance rates. Rhynchomonas sp. cleared APP at volumespecific rates of about $12.0 \times 10^{5}$ body volumes $\mathrm{h}^{-1}$, which is $44 \%$ higher than that of B. saltans, i.e. $8.36 \times$ $10^{5}$ body volumes $\mathrm{h}^{-1}$ (Table 1). However, Rhynchomonas sp. reached a threshold clearance rate at around $70 \mathrm{nl} \mathrm{HNF}{ }^{-1} \mathrm{~h}^{-1}$ when APP concentration decreased to below $0.5 \times 10^{5}$ cells $\mathrm{ml}^{-1}$. The upper threshold of the clearance rate was not encountered for either B. saltans or the mixed culture of HNF.

The average diameter of HNF used in the ingestion experiment was $6.58 \pm 0.48 \mu \mathrm{m}$ and $4.84 \pm 0.88 \mu \mathrm{m}$ for Bodo saltans and Rhynchomonas sp., respectively. The mixed HNF culture was dominated by small ovoid or spherical flagellates of a fairly uniform size of $5.65 \pm$ $0.50 \mu \mathrm{m}$. Based on microscopic observations, an individual HNF could ingest between 1 and 3 APP cells, but HNF of less than $6 \mu \mathrm{m}$ in length never contained more than 1 prey item at a time. The frequency of more than 1 prey in a single HNF was 3.8 to $20 \%$ of the examined Rhynchomonas sp. cells, while for B. saltans and the mixed HNF culture, the frequencies ranged from 4.0 to $47 \%$ and from 5.8 to $58 \%$, respectively (data not shown). The first Rhynchomonas sp. cells with more than 1 APP in the food vacuole were found 180 min after the onset of the experiment; in B. saltans and in the mixed HNF culture cells, several prey were seen already after 45 and $15 \mathrm{~min}$, respectively.

We did not measure the size of APP inside the food vacuoles and have no data on size-selective feeding of HNF. To estimate the grazing impact and the reduction of APP stock, we assumed that the mean uptake of APP is independent of prey size. The carbon flux from Choricystis to HNF varied widely depending on the availability of prey (Table 1). HNF were able to graze on 0.09 to $3.98 \mu \mathrm{g} \mathrm{Cl}^{-1} \mathrm{~h}^{-1}$, and they reduced the carbon stock of APP from less than $1 \%$ up to $5 \%$ in $1 \mathrm{~h}$. The 
most efficient in picoalgae uptake was Bodo saltans at a low APP concentration, but B. saltans also showed a high specific clearance rate, i.e. $31.1 \times 10^{5}$ body volumes $\mathrm{h}^{-1}$. The raptorial Rhynchomonas sp. was least efficient in APP removal. In conditions similar to those in boreal lakes in spring, i.e. at APP and bacteria concentrations of $5.15 \times 10^{5}$ cells ml ${ }^{-1}$ and $0.48 \times 10^{7}$ cells ml $^{-1}$, respectively, the mixed HNF culture could graze on $0.43 \%$ of APP standing stock $\mathrm{h}^{-1}$. Even this modest grazing rate means that on a daily basis flagellates consume ca. $10 \%$ of the APP standing stock.

\section{Growth experiment}

The growth experiments revealed differences between Bodo saltans and Rhynchomonas sp., and the results for the mixed culture generally fell between these monocultures. In all treatments, HNF as well as APP had a period of exponential increase, which was used to calculate the specific growth and grazing rates (Table 2). However, growth rates of HNF cultures did not differ significantly from each other (ANOVA, $F=1.05$, $\mathrm{p}=0.37, \mathrm{n}=27$ ). In the ingestion experiment, Rhynchomonas sp. had the lowest grazing parameters, but in the growth experiment it grew fastest (Fig. 2, Table 2). It doubled during the first $57 \mathrm{~h}$ and had a mean growth rate of $0.85 \mathrm{~d}^{-1}$. When the experiment ended after $6 \mathrm{~d}$, Rhynchomonas sp. had reached a density of $74.2 \times 10^{4}$ cells $\mathrm{ml}^{-1}$, which was 23 times higher than at the onset of the experiment (Fig. 2). The growth rates of B. saltans and the mixed HNF culture were lower, i.e. $0.35 \mathrm{~d}^{-1}$ and $0.54 \mathrm{~d}^{-1}$, respectively, and the final population densities were $5.6 \times 10^{4}$ cells ml ${ }^{-1}$ and $10.0 \times 10^{4}$ cells ml $^{-1}$ (Table 2, Fig. 2). The difference in numbers between the onset and the end of the experiment was 36 and $117 \%$ for $B$. saltans and the mixed culture, respectively. During the exponential growth, the doubling times of HNF ranged from $0.81 \mathrm{~d}$ for Rhynchomonas sp. to $2.00 \mathrm{~d}$ for B. saltans. The mixed HNF culture doubled in $1.25 \mathrm{~d}$.

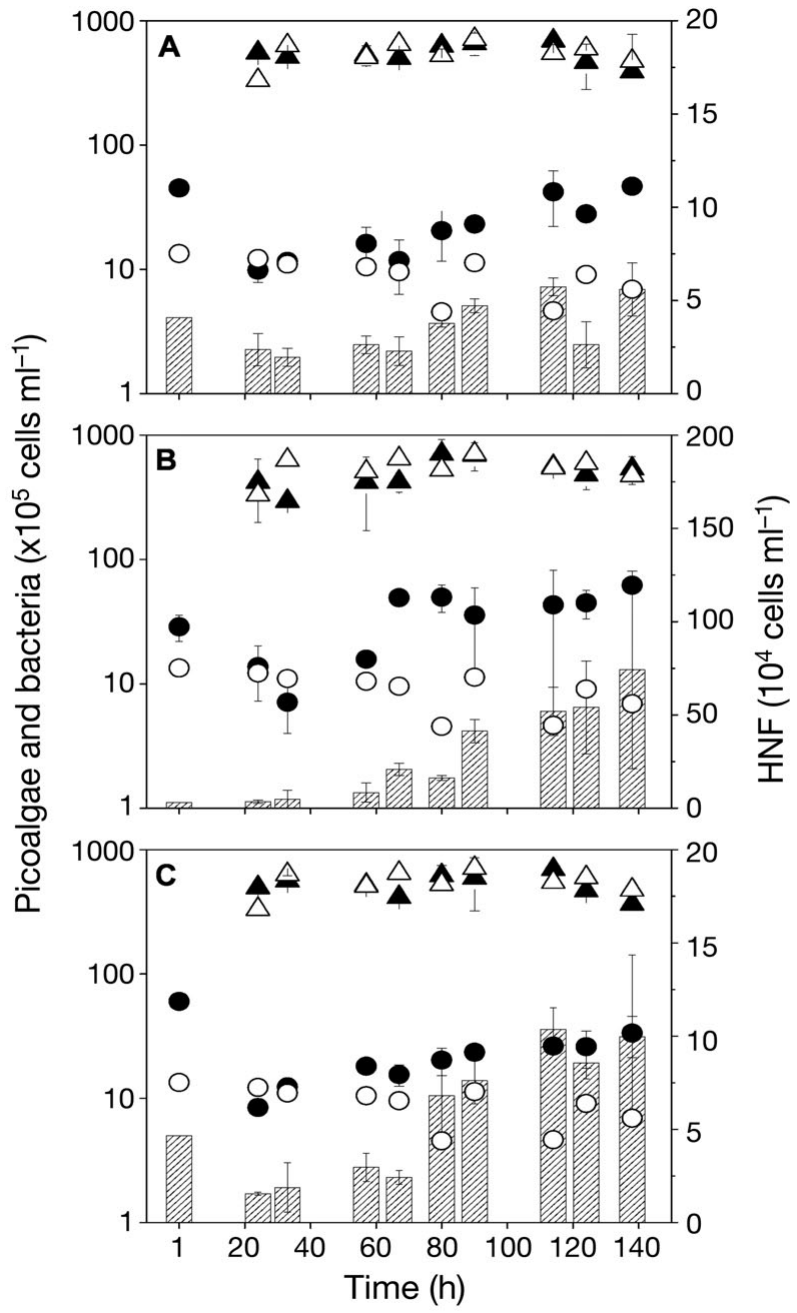

Fig. 2. Changes in density of Choricystis sp. (circles), bacteria (triangles) and heterotrophic nanoflagellates (HNF; bars) during the growth experiment with (A) Bodo saltans, (B) Rhynchomonas sp. and (C) the mixed HNF cultures as the predators. The treatments with predators are indicated with closed symbols and the controls with no predator are shown with the open symbols. Error bars show the range of duplicate cultures. Where error bars are not visible, the range is smaller than the symbol
Table 2. Growth parameters of heterotrophic nanoflagellates (HNF) and autotrophic picoplankton (APP) calculated from the growth experiment. Means \pm SD are shown

\begin{tabular}{|lrrrr|}
\hline Predator type & $\begin{array}{c}\text { HNF } \\
\text { growth rate } \\
\left(\mathrm{d}^{-1}\right)\end{array}$ & $\begin{array}{c}\text { HNF } \\
\text { doubling time }\end{array}$ & $\begin{array}{c}\text { Picoalgae } \\
\text { growth rate } \\
\left(\mathrm{d}^{-1}\right)\end{array}$ & $\begin{array}{c}\text { Picoalgae } \\
\text { grazing rate } \\
\left(\mathrm{d}^{-1}\right)\end{array}$ \\
\hline Bodo saltans & 0.35 & 2.00 & 1.88 & 1.52 \\
Rhynchomonas sp. & 0.85 & \pm 0.63 & \pm 0.43 & \pm 0.29 \\
& \pm 0.32 & \pm 0.21 & \pm 0.19 & \pm 0.97 \\
Mixed culture & 0.54 & 1.27 & 2.21 & 1.96 \\
& \pm 0.19 & \pm 0.35 & \pm 0.26 & \pm 0.25 \\
\hline
\end{tabular}

The presence of Bodo saltans, Rhynchomonas sp. and the mixed HNF culture first resulted in a decrease in APP density (Fig. 2). During the first $24 \mathrm{~h}$ in all cultures the density dropped from between $2.9 \times 10^{6}$ and $6.0 \times 10^{6}$ cells ml ${ }^{-1}$ to $1.1 \times 10^{6}$ cells ml $\mathrm{m}^{-1}$, i.e. 78 and $86 \%$ of APP vanished due to $B$. saltans and the mixed culture of $\mathrm{HNF}$, respectively. With Rhynchomonas sp., the reduction in APP standing stock was smaller (52\%). The grazing rates of HNF calculated during the phase of decline in 
APP were highest with the mixed HNF culture and amounted to $1.96 \mathrm{~d}^{-1}$, while $B$. saltans and Rhynchomonas sp. grazed at rates of $1.52 \mathrm{~d}^{-1}$ and $0.97 \mathrm{~d}^{-1}$, respectively (Table 2). Surprisingly, after the clear decrease of density during the first hours of the experiment, Choricystis demonstrated net growth in all cultures. With $B$. saltans and the mixed HNF culture, APP numbers started to increase after the first experimental day, whereas when Rhynchomonas sp. was present, it took approximately $33 \mathrm{~h}$ before the APP net growth was recorded. During the next $24 \mathrm{~h}$, Choricystis grew with an intrinsic growth rate of $2.23 \mathrm{~d}^{-1}$, reaching at the end of the experiment the highest density among all HNF cultures, i.e. $6.2 \times 10^{6}$ cells ml $^{-1}$ (Fig. 2). The APP reached densities of $4.7 \times 10^{6}$ cells ml ${ }^{-1}$ and $3.3 \times 10^{6}$ cells ml ${ }^{-1}$ with $B$. saltans and the mixed HNF culture, respectively. The corresponding rates of intrinsic growth were $1.88 \mathrm{~d}^{-1}$ and $2.21 \mathrm{~d}^{-1}$. The Choricystis densities in the controls without flagellates were lower than in the treatments (ANOVA, $F=3.72, \mathrm{p}=0.03, \mathrm{n}=9$ ). While the standard stock of APP culture grew at a rate of $0.54 \mathrm{~d}^{-1}$, in the controls of the growth experiment, Choricystis numbers decreased

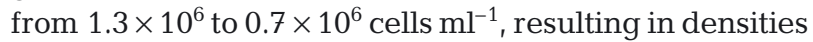
that were 5 to 9 times lower than in the treatments.

Heterotrophic bacteria were present throughout the experiment, with numbers ranging from $2.4 \times 10^{7}$ to 8.6 $\times 10^{7}$ cells $\mathrm{ml}^{-1}$, i.e. at concentrations exploitable by HNF. Over the course of the experiment, the densities of bacteria fluctuated, without clear trends, and we found no significant differences between the controls and the treatments (ANOVA, $F=1.99, \mathrm{p}=0.08, \mathrm{n}=9$ ) (Fig. 2), except for 1 replicate of Rhynchomonas sp. culture (Bonferroni, $\mathrm{p}=0.01, \mathrm{n}=9$ ), where the average number of bacteria was clearly lower than in the control $\left(4.1 \times 10^{7}\right.$ versus $5.5 \times 10^{7}$ cells $\mathrm{ml}^{-1}$ ). It appears that, apart from Choricystis, some bacteria were grazed on during the experiment, but the extent of this grazing is unknown.

Bacteria present in the cultures were large and estimated to contain $35 \mathrm{fg} \mathrm{C}$ cell $^{-1}$ (Theil-Nielsen \& Søndergaard 1998), compared with the calculated $205 \mathrm{fg} \mathrm{C}$ cell $^{-1}$ for the cultured Choricystis cells. Using these values, the proportion of APP-derived carbon in the cultures ranged from 8 to $46 \%$ of total carbon. The relatively low contribution of APP carbon $(\sim 12.5 \%)$ at the onset of the experiment increased significantly in all treatment cultures within $5 \mathrm{~d}$, and finally APP represented $41 \%$ of carbon in the cultures of Rhynchomonas sp. and Bodo saltans, and $34 \%$ in the mixed culture of HNF.

\section{DISCUSSION}

All HNF ingested APP at prey concentrations similar to those in nature. This indicates that HNF are likely to exploit APP in boreal lakes where the popu- lation density of eukaryotic APP is around $0.3 \times 10^{5}$ cells $\mathrm{ml}^{-1}$ (Jasser \& Arvola 2003), compared with the concentrations of $(0.06$ to 11.63$) \times 10^{5}$ cells ml ${ }^{-1}$ used in the ingestion experiments. Eukaryotic APP, including the freshwater Choricystis species, are especially abundant in spring (Hepperle \& Krienitz 2001, Hepperle \& Schlegel 2002). The density and biomass of HNF in boreal lakes are also highest at the beginning of the growing season, varying from $(0.5$ to 3.0$) \times 10^{3}$ cells $\mathrm{ml}^{-1}$ (Ventelä 1999). In aquatic environments, bacterial density exceeds APP numbers by 1 or 2 orders of magnitude (Pick \& Caron 1987), and a protozoan diet is unlikely to comprise only APP cells. The carbon content per cell volume of bacteria and APP is of the same order of magnitude (Bratbak 1985, Søndergaard 1991), but if protozoa consume even a few APP cells daily, the large cell size of picoalgae relative to bacteria results in a high contribution to total ingested carbon (Cleven 1995). Therefore, APP may contribute significantly to the diet of small protozoa (Caron et al. 1991), i.e. $30 \%$ of the diet of bodonid species is composed of APP carbon (Šimek et al. 1997). By taking into account the average volume of APP and HNF cells used in our grazing experiments as well as the HNF doubling time and the ingestion rate at the highest prey concentrations, we ended up with a $40 \%$ contribution of APP to the diet of Bodo saltans and $33 \%$ to the diet of the mixed culture. Rhynchomomas sp. and B. saltans are known to be bacterivous flagellates (Boenigk \& Arndt 2000a), and in non-axenic cultures, besides Choricystis, HNF could also exploit accompanying bacteria.

We found the ingestion rates of HNF feeding on Choricystis to be lower than reported for flagellates grazing on bacteria or picocyanobacteria (Pernthaler et al. 1997, Christaki et al. 2002, 2005). The size of prey is generally believed to play a major role in prey selection, and in laboratory experiments with flagellates, the predator to prey size ratio ranged from 2:1 to $8: 1$ (Chrzanowski \& Šimek 1990). Interceptive and raptorial HNF (i.e. Bodo and Rhynchomonas, respectively) prefer relatively large prey items (Šimek et al. 1997, Boenigk \& Arndt 2000a,b, Koton-Czarnecka \& Chróst 2003). The predator to prey size ratio in our experiments was on average between $2: 1$ and 3:1. Thus, size selection was probably not the reason for low ingestion rates. Flagellates used were 'naïve' to picoalgal prey, but were precultured with bacteria. However, Christaki et al. (2005) showed ingestion and clearance rates of HNF naïve to picoalgae to be close to bacterial consumption, and Dolan \& Šimek (1997) found no significant difference in cells exposed to or naïve to Synechococcus. Thus, physiological conditions of the flagellates or the prey cell surface properties and the digestibility of the strain are probably of great impor- 
tance (Boenigk et al. 2001). The later decrease in ingestion might be related to processing of food vacuoles (Boenigk et al. 2001). The delayed digestion may be due to generally slower metabolism at lower temperatures (Sherr et al. 1988). We carried out our experiments at $10^{\circ} \mathrm{C}$, where $\mathrm{HNF}$ metabolism is 2.8 times slower than at 20 to $25^{\circ} \mathrm{C}$ (Sherr et al. 1988). Low or a lack of ingestion at the end of the grazing experiment could be due to the decrease in prey concentration below the clearance capacity of HNF.

Although the interpretation of the grazing impact on the basis of the short-term experiments requires caution, we attempted to quantify carbon transfer from picoalgae to HNF. At prey concentrations similar to the densities common in boreal lakes in spring (Ventelä 1999, Jasser \& Arvola 2003), the loss of picoalgae due to mixed HNF culture was $10 \%$, compared with 17 to $56 \%$ due to total microzooplankton grazing reported in natural environments (Kimmance et al. 2007). The in situ grazing rates of HNF on picoalgae vary from 0.08 to $1.78 \mathrm{~d}^{-1}$ (Hirose et al. 2008), compared with 0.96 to $2.40 \mathrm{~d}^{-1}$ obtained in laboratory experiments (Christaki et al. 2005). Our results fall into the laboratory-derived range, showing that HNF have a high potential for grazing of picoalgae. Sakka et al. (2000) demonstrated that protistan herbivory is greater than bacterivory. In fact, small HNF readily utilise abundant APP, and, rather than being solely bacterivores, they are omnivores (Sherr \& Sherr 2002).

The clearance rates in our experiments varied by 3 orders of magnitude, but the highest value obtained for the mixed culture of HNF grazing on picoalgae was only slightly lower than the previously reported maximum of $150 \mathrm{nl} \mathrm{HNF}{ }^{-1} \mathrm{~h}^{-1}$ (Sherr et al. 1991). Specific clearance rates were also in accordance with the upper limit given by Boenigk \& Arndt (2000b). The clearance rates were sensitive to prey concentration, with higher values at lower Choricystis concentrations. A general increase in HNF clearance rates with decreasing concentrations of algal prey is expected, based on the optimal diet theory (Sherr \& Sherr 2002) and experimental results (e.g. Jürgens \& DeMott 1995, Christaki et al. 2002). High clearance rates at lower prey concentrations are an indication of food limitation. Considering the effort required by an individual protist to obtain sufficient carbon for reasonable growth, at low to medium prey biomass small flagellates have to clear prey at rates of 0.3 to $0.8 \mu \mathrm{cell}^{-1} \mathrm{~h}^{-1}$ (Sherr \& Sherr 2002). In our grazing experiments, the lowest food concentrations were only 10 to $30 \mu \mathrm{g} \mathrm{C}^{-1}$, resulting in clearance rates similar to those reported for foodlimited HNF (Sherr \& Sherr 2002).

The differences in clearance rates between HNF species depend on multiple factors, including speciesspecific capture and ingestion (Boenigk \& Arndt 2000b). We treated the mixed culture of HNF as a 'black box', an approach that ignores the complexity of predator-prey feeding interactions. Low clearance rates of HNF mixed cultures are attributed to heterogeneous feeding patterns, i.e. existence of specialised feeders as well as forms that do not feed on APP (Christoffersen 1994, Boenigk \& Arndt 2000b). Both HNF monocultures used here feed on large particles (Boenigk \& Arndt 2000b), but differ in their feeding behaviour. Rhynchomonas sp. is adapted to live and feed on surfaces by scraping attached bacteria. Thus, during the long-term experiment, when surfaces became colonised with bacteria, Rhynchomonas sp. benefitted from this and reached higher growth rates. Bodo saltans is a free-living flagellate that can attach to the surface by the tip of a posterior flagellum, while the anterior flagellum is used to search for food particles. Attached flagellates create a large-scale flow around themselves with their flagella (Christensen-Dalsgaard \& Fenchel 2003). Subsequently, attachment should increase the contact rate and capture of food particles (Pfandl et al. 2004).

In all treatments, HNF grew on a diet including APP, but the growth rates observed in our experiments were lower than those recorded in other laboratory cultures with HNF (Weitere et al. 2005) and differed between HNF species. Rhynchomonas sp. yielded the highest growth rates (Table 2), whereas Bodo saltans and the mixed culture of HNF grew slower despite significant ingestion (Table 1). Picoalgae can be of dietary importance, but the HNF response to APP prey varies (Parslow et al. 1986, Christaki et al. 2005). Some HNF do not consume picoalgae at all, whereas others can grow on a pure APP diet, attaining high growth and grazing rates (Parslow et al. 1986, Boenigk et al. 2001, Guillou et al. 2001). According to Christaki et al. (2005), for instance, Rhynchomonas sp. does not ingest eukaryotic APP, but we found Rhynchomonas sp. to ingest Choricystis and grow on a diet consisting partly of APP. Although APP are reported as less edible to protozoa than bacteria (Kuuppo et al. 2003), picoalgae may be of high nutritional value, as they contain polyunsaturated fatty acids (Krienitz \& Wirth 2006). In contrast to our experiments, laboratory cultures are usually grown at $20^{\circ} \mathrm{C}$ and shaken constantly, which influences the uptake of suspended prey, but can harm flagella. Considering that the $Q_{10}$ for HNF between 10 and $20^{\circ} \mathrm{C}$ is close to 3 (Rose \& Caron 2007), our lowtemperature, static cultures attained good growth, similar to Delaney (2003). In fact, in our growth experiments, the doubling times of HNF were shorter than obtained for flagellates growing in situ with sufficient food (Christaki et al. 2001) and were in accordance with values reported in eutrophic lakes in spring, when HNF growth is not limited by food (Weisse 1997). 
Our results suggest that HNF consumption alone is insufficient to strongly control the APP population. HNF can feed on picoalgae, but APP can grow at least as fast as they are grazed (Christaki et al. 2001, Sato et al. 2007). The growth rate of APP in natural ecosystems is usually around $0.7 \mathrm{~d}^{-1}$ (Callieri \& Stockner 2002), while in our study it reached $2.23 \mathrm{~d}^{-1}$. The unexpected increase in APP numbers during the experiments implies stimulation of Choricystis growth in the presence of HNF. Reckermann \& Veldhuis (1997) observed a similar increase in APP growth under high grazing pressure. In terrestrial ecosystems, grazing of herbivores enhances the growth of plants through the socalled overcompensation mechanism (Agrawal 2000). It is somewhat questionable whether the same phenomenon occurs in aquatic planktonic ecosystems. The growth of APP can be enhanced through nutrient regeneration and/or organic products excreted by protozoa (Laybourn-Parry \& Parry 2000). Thus, a direct nutrient liberation through HNF simultaneously grazing on bacteria could also explain the phenomenon (Sato et al. 2007, Allende 2009).

Although the APP culture appeared morphologically uniform, it may have been phylogenetically and physiologically diverse (Herdman et al. 1979). Genetically distinguishable strains exposed to grazing may cope differentially under stress conditions, resulting in discernibly different growth and loss rates. Postius \& Ernst (1999) observed a genotype-specific prey selection by Bodo saltans, i.e. it was unable to proliferate on a diet of a certain APP strain, which, in contrast, was the preferred prey of another cultured HNF. We tentatively analysed the Choricystis sp. culture using culture-independent detection techniques and noticed an unexpected genetic heterogeneity (G. Bręk-Laitinen et al. unpubl. data). The culture may have contained at least 2 different genotypes. Possibly, while 1 picoalgal strain was ingested at higher rates, the other gained an advantage and overgrew the APP culture.

This is the first quantitative study on species-specific consumption of picoalgae by freshwater HNF. On the species level, we observed diverse reactions to picoalgae, as HNF growth efficiency was not always proportional to picoalgal prey consumption. Simultaneously, the results of the mixed culture fall between those of the monocultures, as the community grazing rates are combined from varying nutritional strategies. Although the results from laboratory studies cannot be directly extrapolated to the field, they reveal information on the mechanisms of predator-prey interactions. We demonstrate that HNF may have a clear effect on picoalgae, even at fairly low temperatures, and they can ingest a significant portion of APP. Surprisingly, HNF grazing produced an enhancing effect on APP growth. Thus, we conclude that HNF grazing is not only important in reducing the standing stock of APP, but may constitute a positive feedback mechanism. This implies that HNF grazing is both a top-down and a bottom-up regulator of APP. However, we acknowledge that HNF are not the only grazers controlling picoalgae, but act alongside mixotrophic flagellates and ciliates.

Acknowledgements. The Choricystis sp. culture was kindly supplied by E. Peltomaa (University of Helsinki, Lammi Biological Station, Finland). This study was financially supported by the Maj and Tor Nessling Foundation, project no. 2005269. We express gratitude to anonymous reviewers, whose comments significantly improved the manuscript. C. A. Pelli kindly edited the language.

\section{LITERATURE CITED}

Agrawal AA (2000) Overcompensation of plants in response to herbivory and the by-product benefits of mutualism. Trends Plant Sci 5:309-313

Allende K (2009) Combined effects of nutrients and grazers on bacterioplankton and phytoplankton abundance in an Antarctic lake with even food-chain links. Polar Biol 32:493-501

Auer B, Arndt H (2001) Taxonomic composition and biomass of heterotrophic flagellates in relation to lake trophy and season. Freshw Biol 46:959-972

Baudoux AC, Veldhuis MJW, Noordeloos AAM, van Noort G, Brussaard CPD (2008) Estimates of virus- vs. grazing induced mortality of picophytoplankton in the North Sea during summer. Aquat Microb Ecol 52:69-82

Boenigk J, Arndt H (2000a) Comparative studies on the feeding behavior of two heterotrophic nanoflagellates: the filter-feeding choanoflagellate Monosiga ovata and the raptorial-feeding kinetoplastid Rhynchomonas nasuta. Aquat Microb Ecol 22:243-249

Boenigk J, Arndt H (2000b) Particle handling during interception feeding of four species of heterotrophic nanoflagellates. J Eukaryot Microbiol 47:350-358

Boenigk J, Matz C, Jurgens K, Arndt H (2001) The influence of preculture conditions and food quality on the ingestion and digestion of three species of heterotrophic nanoflagellates. Microb Ecol 42:168-176

Børsheim KY, Bratbak G (1987) Cell volume to cell carbon conversion factors for a bacterivorous Monas sp. enriched from seawater. Mar Ecol Prog Ser 36:171-175

> Bratbak G (1985) Bacterial biovolume and biomass estimations. Appl Environ Microbiol 49:1488-1493

Callieri C, Stockner JG (2002) Freshwater autotrophic picoplankton: a review. J Limnol 61:1-14

Caron DA, Lim EL, Miceli G, Waterbury JB, Valois FW (1991) Grazing and utilization of chroococcoid cyanobacteria and heterotrophic bacteria by protozoa in laboratory cultures and a coastal plankton community. Mar Ecol Prog Ser 76: 205-217

> Christaki U, Giannakoutou A, Van Wambeke F, Gregori G (2001) Nanoflagellate predation on auto- and heterotrophic picoplankton in the oligotrophic Mediterranean Sea. J Plankton Res 23:1297-1310

Christaki U, Courties C, Karayanni H, Giannakoutou A, Maravelias C, Kormas KA, Lebaron P (2002) Dynamic characteristics of Prochlorococcus and Synechococcus 
consumption by bacterivorous nanoflagellates. Microb Ecol 43:341-352

Christaki U, Vazquez-Dominguez E, Courties C, Lebaron P (2005) Grazing impact of different heterotrophic nanoflagellates on eukaryotic (Ostreococcus tauri) and prokaryotic picoautotrophs (Prochlorococcus and Synechococcus). Environ Microbiol 7:1200-1210

Christensen-Dalsgaard KK, Fenchel T (2003) Increased filtration efficiency of attached compared to free-swimming flagellates. Aquat Microb Ecol 33:77-86

Christoffersen K (1994) Variations of feeding activities of heterotrophic nanoflagellates on picoplankton. Mar Microb Food Webs 8:111-123

> Chrzanowski TH, Šimek K (1990) Prey-size selection by freshwater flagellated protozoa. Limnol Oceanogr 35: $1429-1436$

Cleven EJ (1995) Grazing-Kontrolle der Bakterien- und Flagellaten (HNF)-Produktion durch ausgewähltes Protozooplankton im Bodensee. $\mathrm{PhD}$ thesis, University of Constance

> Delaney MP (2003) Effects of temperature and turbulence on the predator-prey interactions between a heterotrophic flagellate and a marine bacterium. Microb Ecol 45: 218-225

Dolan JR, Šimek K (1997) Processing of ingested matter in Strombidium sulcatum, a marine ciliate (Oligotrichida). Limnol Oceanogr 42:393-397

Dolan JR, Šimek K (1998) Ingestion and digestion of an autotrophic picoplankter, Synechococcus, by a heterotrophic nanoflagellate, Bodo saltans. Limnol Oceanogr 43:1740-1746

Fenchel T (1987) Ecology of protozoa. The biology of free-living phagotrophic protists. Springer Verlag, New York, NY

Guillard RRL, Sieracki MS (2005) Counting cells in cultures with the light microscope. In: Andersen RA (ed) Algal culturing techniques. Elsevier Academic Press, New York, NY, p 239-252

> Guillou L, Jacquet S, Chretiennot-Dinet MJ, Vaulot D (2001) Grazing impact of two small heterotrophic flagellates on Prochlorococcus and Synechococcus. Aquat Microb Ecol 26:201-207

Haberey M, Stockem W (1971) Amoeba proteus: Morphologie, Zucht und Verhalten. Mikrokosmos 60:33-42

Heinbokel JF (1978) Studies on the functional role of tintinnids in the Southern California Bight. I. Grazing and growth rates in laboratory cultures. Mar Biol 47:177-189

Hepperle D, Krienitz L (2001) Systematics and ecology of chlorophyte picoplankton in German inland waters along a nutrient gradient. Int Rev Ges Hydrobiol 86:269-284

Hepperle D, Schlegel I (2002) Molecular diversity of eukaryotic picoalgae from three lakes in Switzerland. Int Rev Ges Hydrobiol 87:1-10

Herdman M, Janvier M, Waterbury JB, Rippka R, Stanier RY, Mandel M (1979) Deoxyribonucleic acid base composition of cyanobacteria. J Gen Microbiol 111:63-71

> Hirose M, Katano T, Nakano SI (2008) Growth and grazing mortality rates of Prochlorococcus, Synechococcus and eukaryotic picophytoplankton in a bay of the Uwa Sea, Japan. J Plankton Res 30:241-250

Ivanikova NV, Popels LC, McKay RML, Bullerjahn GS (2007) Lake Superior supports novel clusters of cyanobacterial picoplankton. Appl Environ Microbiol 73:4055-4065

> Jasser I, Arvola L (2003) Potential effects of abiotic factors on the abundance of autotrophic picoplankotn in four boreal lakes. J Plankton Res 25:873-883

> Jürgens K, DeMott WR (1995) Behavioral flexibility in prey selection by bacterivorous nanoflagellates. Limnol Oceanogr 40:1503-1507
Keto J, Tallberg P, Malin I, Vääränen P, Vakkilainen K (2005) The horizon of hope for L. Vesijärvi, southern Finland: 30 years of water quality and phytoplankton studies. Verh Int Ver Theor Angew Limnol 29:448-452

Kimmance SA, Wilson WH, Archer SD (2007) Modified dilution technique to estimate viral versus grazing mortality of phytoplankton: limitations associated with method sensitivity in natural waters. Aquat Microb Ecol 49: 207-222

Koton-Czarnecka M, Chróst RJ (2003) Protozoans prefer large and metabolically active bacteria. Pol J Environ Stud 12: $325-334$

Krienitz L, Wirth M (2006) The high content of polyunsaturated fatty acids in Nannochloropsis limnetica (Eustigmatophyceae) and its implication for food web interactions, freshwater aquaculture and biotechnology. Limnologica 36:204-210

Kuuppo P, Samuelsson K, Lignell R, Seppälä J, Tamminen T, Andersson A (2003) Fate of increased production in latesummer plankton communities due to nutrient enrichment of the Baltic Proper. Aquat Microb Ecol 32:47-60

> Landry MR, Kirshstein J, Constantinou J (1995) A refined dilution technique for measuring the community grazing impact of microzooplankton, with experimental tests in the central equatorial Pacific. Mar Ecol Prog Ser 120: $53-63$

Laybourn-Parry J, Parry J (2000) Flagellates and the microbial loop. In: Leadbeater BSC, Green JC (eds) The flagellates. Taylor \& Francis, London, p 216-239

> Liu H, Campbell L, Landry MR (1995) Growth and mortality rates of Prochlorococcus and Synechococcus measured with a selective inhibitor technique. Mar Ecol Prog Ser 116:277-287

Loret P, Le Gall S, Dupuy C, Blanchot J and others (2000) Heterotrophic protists as a trophic link between picocyanobacteria and the pearl oyster Pinctada margaritifera in the Takapoto lagoon (Tuamotu Archipelago, French Polynesia). Aquat Microb Ecol 22:215-226

Mózes A, Vörös L (2004) Unusual picoplankton communities in the frozen Lake Balaton. Hidrológ Közlöny 84:85-87

Mózes A, Présing M, Vörös L (2006) Seasonal dynamics of picocyanobacteria and picoeukaryotes in a large shallow lake (Lake Balaton, Hungary). Int Rev Ges Hydrobiol 91:38-50

> Parslow JS, Doucette GJ, Taylor FJR, Harrison PJ (1986) Feeding by the zooflagellate Pseudobodo sp. on the picoplanktonic prasinomonad Micromonas pusilla. Mar Ecol Prog Ser 29:237-246

Pernthaler J, Posch T, Šimek K, Vrba J, Amann R, Psenner R (1997) Contrasting bacterial strategies to coexist with a flagellate predator in an experimental microbial assemblage. Appl Environ Microbiol 63:596-601

Personnic S, Domaizon I, Dorigo U, Berdjeb L, Jacquet S (2009) Seasonal and spatial variability of virio-, bacterio-, and picophytoplanktonic abundances in three peri-alpine lakes. Hydrobiologia 627:99-116

> Pfandl K, Posch T, Boenigk J (2004) Unexpected effects of prey dimensions and morphologies on the size selective feeding by two bacterivorous flagellates (Ochromonas sp. and Spumella sp.). J Eukaryot Microbiol 51:626-633

> Pick FR, Caron DA (1987) Picoplankton and nanoplankton biomass in Lake Ontario: relative contribution of phototrophic and heterotrophic communities. Can J Fish Aquat Sci 44:2164-2172

Postius C, Ernst A (1999) Mechanisms of dominance: coexistence of picocyanobacterial genotypes in a freshwater ecosystem. Arch Microbiol 172:69-75 
Reckermann M, Veldhuis MJW (1997) Trophic interactions between picophytoplankton and micro- and nanozooplankton in the western Arabian Sea during the NE monsoon 1993. Aquat Microb Ecol 12:263-273

Richardson TL, Jackson GA (2007) Small phytoplankton and carbon export from the surface ocean. Science 315: $838-840$

Rose JM, Caron DA (2007) Does low temperature constrain the growth rates of heterotrophic protists? Evidence and implications for algal blooms in cold waters. Limnol Oceanogr 52:886-895

Sakka A, Legendre L, Gosselin M, Delesalle B (2000) Structure of the oligotrophic planktonic food web under low grazing of heterotrophic bacteria: Takapoto Atoll, French Polynesia. Mar Ecol Prog Ser 197:1-17

Sato M, Takeda S, Furaya K (2006) Effects of long-term sample preservation on flow cytometric analysis of natural populations of pico- and nanophytoplankton. J Oceanogr 62:903-908

Sato M, Yoshikawa T, Takeda S, Furyya K (2007) Application of the size-fractionation method to simultaneous estimation of clearance rates by heterotrophic flagellates and ciliates of pico- and nanophytoplankton. J Exp Mar Biol Ecol 349:334-343

Sherr EB, Sherr BF (2002) Significance of predation by protists in aquatic microbial food webs. Antonie Leeuwenhoek 81:293-308

Sherr BF, Sherr EB, Rassoulzadegan F (1988) Rates of digestion of bacteria by marine phagotrophic protozoa: temperature dependence. Appl Environ Microbiol 54:1091-1095

Sherr EB, Sherr BF, McDaniel J (1991) Clearance rates of $<6 \mu \mathrm{m}$ fluorescently labeled algae (FLA) by estuarine protozoa: potential grazing impact of flagellates and ciliates. Mar Ecol Prog Ser 69:81-92

Sherr BF, Sherr EB, McDaniel J (1992) Effect of protistan grazing on the frequency of dividing cells in bacterioplankton assemblages. Appl Environ Microbiol 58: 2381-2385

Šimek K, Hartman P, Nedoma J, Pernthaler J, Springman D, Vrba J, Psenner R (1997) Community structure, picoplankton grazing and zooplankton control of heterotrophic nanoflagellates in a eutrophic reservoir during the summer phytoplankton maximum. Aquat Microb Ecol 12: 49-63

Editorial responsibility: Fereidoun Rassoulzadegan, Villefranche-sur-Mer, France
Šimek K, Kojecká P, Nedoma J, Hartman P, Vrba J, Dolan JR (1999) Shifts in bacterial community composition associated with different microzooplankton size fractions in a eutrophic reservoir. Limnol Oceanogr 44:1634-1644

Søndergaard M (1991) Phototrophic picoplankton in temperate lakes: seasonal abundance and importance along a trophic gradient. Int Rev Ges Hydrobiol 76:505-522

Stockner JG (1988) Phototrophic picoplankton: an overview from freshwater and marine ecosystems. Limnol Oceanogr 33:756-775

Straškrábová V, Izmestyeva LR, Maksimova EA, Fietz S and others (2005) Primary production and microbial activity in the euphotic zone of Lake Baikal (Southern Basin) during late winter. Glob Planet Change 46:57-73

Theil-Nielsen J, Søndergaard M (1998) Bacterial carbon biomass calculated from biovolumes. Arch Hydrobiol 141: 195-207

Ventelä AM (1999) Lake restoration and trophic interactions: Is the classic food chain theory sufficient? $\mathrm{PhD}$ thesis, University of Turku

Vörös L, Gulyas P, Nemeth J (1991) Occurrence, dynamics and production of picoplankton in Hungarian shallow lakes. Int Rev Ges Hydrobiol 76:617-629

Weisse T (1993) Dynamics of autotrophic picoplankton in marine and freshwater ecosystems. Adv Microb Ecol 13: 327-370

Weisse T (1997) Growth and production of heterotrophic nanoflagellates in a meso-eutrophic lake. J Plankton Res 19:703-722

- Weitere M, Bergfeld T, Rice SA, Matz C, Kjelleberg S (2005) Grazing resistance of Pseudomonas aeruginosa biofilms depends on type of protective mechanism, developmental stage and protozoan feeding mode. Environ Microbiol 7:1593-1601

> Worden AZ, Binder BJ (2003) Application of dilution experiments for measuring growth and mortality rates among Prochlorococcus and Synechococcus populations in oligotrophic environments. Aquat Microb Ecol 30:159-174

- Worden AZ, Nolan JK, Palenik B (2004) Assessing the dynamics and ecology of marine picophytoplankton: the importance of the eukaryotic component. Limnol Oceanogr 49:168-179

Zidarova R, Temniskova D, Dzhambazov B (2009) Karyological and endosymbiotic notes on two Choricystis species (Trebouxiophyceae, Chlorophyta). Biologia 64:43-47

Submitted: October 20, 2009; Accepted: August 31, 2010, Proofs received from author(s): October 22, 2010 